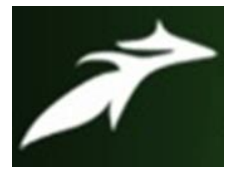

Amir Zenunović et al, International Journal of Advances in Agricultural Science and Technology,

Vol.8 Issue.8, August-2021, pg. 102-109

ISSN: 2348-1358

Impact Factor: 6.057

NAAS Rating: 3.77

\title{
Influence of the Application of Organic Selenium in Duck Concentrate Mixtures on the Sensory Properties of Duck Meat
}

\author{
Amir Zenunović; Husejin Keran; Amir Hasić; Toni Babić \\ Faculty of Technology, University of Tuzla, Department of Agronomy
}

Email: amir.zenunovic@untz.ba

DOI: 10.47856/ijaast.2021.v08i8.011

\begin{abstract}
There are data in the literature on the influence of higher amounts of organic selenium on production results, and the obtained results indicate that high levels of organic selenium added to feed (even up to $15 \mathrm{mg} / \mathrm{kg}$ ) of chickens did not have a negative effect on production results. Also, in the literature related to chicken nutrition there is data on the use of different forms (inorganic, organic) and different amounts of selenium on carcass meat, $\mathrm{pH}$ value of meat, ability to bind water, chemical parameters of meat quality, oxidative stability of meat, and and on the sensory properties of broiler meat. Of particular importance are the studies of the possibility of using increased amounts of organic selenium in poultry nutrition in order to enrich meat with selenium. This is of particular importance for the nutritional value of meat, and in connection with this, human health. The aim of this study was to investigate the effect of adding different amounts of organic selenium (ALKOSEL $® \mathrm{R} 397$ ) in concentrate mixtures on the sensory properties of meat streams.
\end{abstract}

Keywords: organic selenium, meat quality, sensory properties of meat, nutritional value of meat

\section{Introduction}

Poultry meat, including duck meat, has a high nutritional value (over $20 \%$ protein and less than $5 \%$ fat in the meat of breasts and drumsticks with carbata). These data refer to hybrid duck lines intended for fattening.

Foods of animal origin are extremely important in the diet of a growing population of people. In the poultry industry, meat and eggs are a source of quality protein, energy, vitamins and minerals (Newman et al., 2002).

Nutrients synthesized in the animal organism are easier to use and have higher biological values for humans compared to plant foods (Domaćinović, 2006).

Interest in better production results in fattening, meat yield parameters (carcass meatiness), quality and nutritional value of meat is present in the cultivation of all animal species intended for meat production. Today, it is a well-known fact in the world that animal nutrition can affect the nutritional value of meat, milk, eggs, and that it is one of the ways to obtain food with special properties known as functional food. Seleniumenriched foods can also be considered functional foods.

But also sar. (2007a) in a study comparing the characteristics between duck and chicken meat came to the conclusion that the cooking mud in duck meat was higher compared to chicken meat and that the cutting force of muscle tissue was higher in duck meat compared to chicken meat. The loss in cooking was higher in chest muscles that contained higher levels of lipids. The breast muscles of fattened musk ducks received the lowest score, while the muscle derived from ad libitum-fed Peking ducks had the highest score for juiciness. Girard et al. (1993) also found that the breast muscles of ducks fed ad libitum were juicier compared to the pectoral muscle fat of ducks fattened on a meal basis. In contrast, pectoral muscle containing higher lipid levels was 


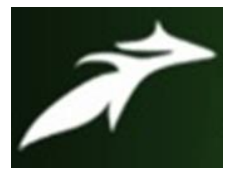

Amir Zenunović et al, International Journal of Advances in Agricultural Science and Technology, Vol.8 Issue.8, August-2021, pg. 102-109

ISSN: 2348-1358

Impact Factor: 6.057

NAAS Rating: 3.77

rated as juicier in fattened geese of the Landaise strain (Baeza and Leclercq, 1998). Chartrin et al. (2006a) found that there is a positive correlation between meat juiciness and water content in meat. However, they state that a negative correlation has been found between juiciness and breast mass.

Consumption of chicken meat is constantly increasing, so attempts to change the composition of meat fat, in order to obtain better quality food, have become greater (Dupler, 2001). Prolonged intake of n-6 series fatty acids and low intake of n-3 series acids in food, poses a risk to human health, in terms of more frequent occurrence of cancer, cardiovascular and cerebrovascular diseases. Therefore, there is a need to improve the ratio of n-3 and n-6 series fatty acids in poultry feed (Okuynama and Ikemoto, 1999). Although n-3 series fatty acids have a positive effect on the composition of chicken meat, this fact should be cautiously accepted, due to the negative impact on the sensory properties of chicken meat and its oxidative stability (Hargins and Elswyk, 1993).

Consumer attention is drawn to a large number of meat properties. These are appearance, texture, color (Lin et al., 1989), as well as tenderness, juiciness, odor (Janssens, 1998), and some other characteristics. Among these characteristics, appearance is the most important and it can first influence the customer's decision whether or not to buy a meat product (Sheehy et al., 1997). Consumers want to get meat with minimal water loss during preparation and cooking. Thus, water retention ability (Mahan and Kim, 1999) as well as color (Froning, 1995) and desirable odors (Sheehy et al., 1997) are the most important characteristics of meat quality (Baeza, 2006).

There are numerous meat quality parameters that attract consumers such as: appearance, color, texture, softness, juiciness and aroma (Janssens, 1998). The ability to bind water, ie weight loss by squeezing, as well as color are the most important characteristics of meat (Mahan and Kim, 1999). According to Rede and Ljiljana Petrović (1997) and Čepin and Čepon (2001), diet has a dominant influence on meat quality.

In the review, Natalija Džinić et al. (2006) examined the influence of added selenium from different sources, and in different amounts on the technological quality of the pectoral muscles. The results of this experiment showed that the addition of organic selenium in the amount of $0.3 \mathrm{mg} / \mathrm{kg}$ to food significantly reduced the loss of weight by squeezing, and the color of the pectoral muscles in these chickens was the darkest, while the proportion of red was also the highest.

In the experiment of Markovic Radmila (2007), the use of the organic form of selenium in chicken fattening with the addition of vitamin $\mathrm{E}$ in the amount of 100 IU significantly influenced the improvement of meat quality (color, texture, fatty acid composition).

Terms related to color are: subjective, ie psychosensory (brightness, sharpness, tone, chromium saturation and fullness); and objective relating to stimuli and divided into psychophysical and psychometric.

\section{Materials and Methods}

The study of the influence of the application of organic selenium in concentrate mixtures of ducklings on the sensory properties of duck meat was conducted on a total of 240 one - day - old ducklings. Upon arrival at the immigration facility, and before being placed in the box, the one-day-old ducklings were weighed on a digital scale with a tolerance of $\pm 1 \mathrm{~g}$ and each individual was marked with a ring on its leg with its own number. In all repetitions, the ducklings were placed in special cardboard boxes for the first week for easier temperature control. Immediately during the weighing, groups of 20 ducklings were randomly formed and arranged in prepared and marked boxes. Ducklings were randomly divided into 4 experimental groups (K0, K1, K2 and K3). There were 60 one-day-old ducklings in each experimental group, and fattening was performed in three repetitions of 20 ducklings. The research plan is shown in Table 1. 


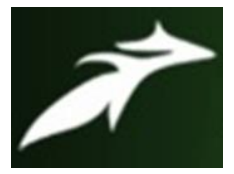

Amir Zenunović et al, International Journal of Advances in Agricultural Science and Technology, Vol.8 Issue.8, August-2021, pg. 102-109

ISSN: 2348-1358

Impact Factor: 6.057

NAAS Rating: 3.77

Table 1. Research implementation plan

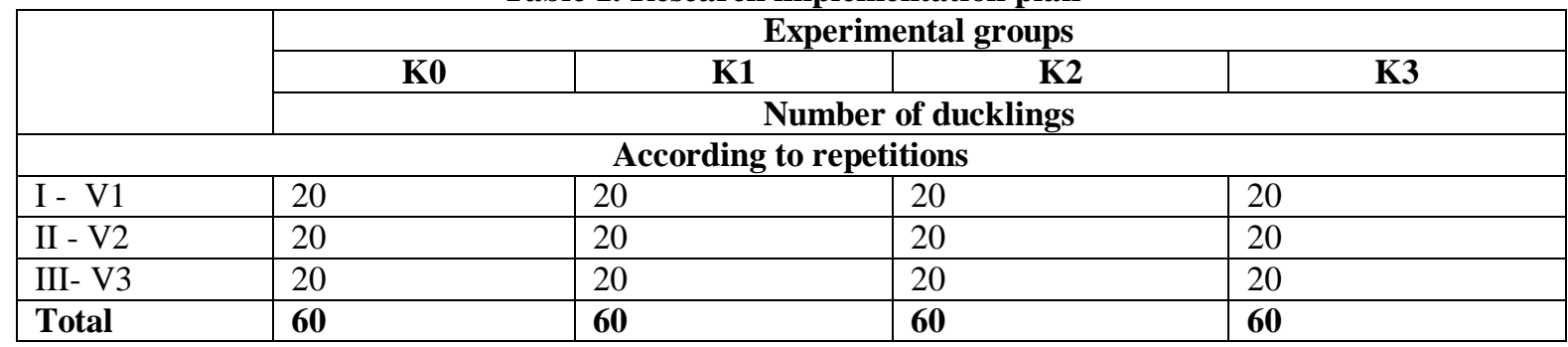

\section{Duckling diet}

The ducklings are in two phases of feeding duration in fattening, fed with two and nutritionally different concentrate feed mixtures: starter (from 1st to 14th day) and finisher (from 15th to 49th day of fattening). The first, the control group of ducklings (K0) during fattening received food without added selenium in both phases of fattening.

The second group of ducklings (K1) was fed with food in both phases of fattening as well as the control group, but with the addition of $0.2 \mathrm{mg} / \mathrm{kg}$ of organic selenium (commercial preparation, Alkosel R 397, France).

The third group of ducks (K2) used food with $0.4 \mathrm{mg} / \mathrm{kg}$ of organic selenium in fattening, and the fourth group of ducks (K3) with $0.6 \mathrm{mg} / \mathrm{kg}$ of organic selenium.

The experiment lasted 7 weeks (49 days), and the food recipe for individual stages of fattening was adjusted to the selected duck hybrid.

At the beginning of fattening, the chemical composition of the concentrate mixtures as well as the selenium content were determined (to determine the total selenium content, i.e. basal derived from food and to add organic selenium).

During fattening every week and at the end of fattening, each individual was weighed individually and for each of these periods, ie for total fattening, growth, consumption and conversion of food were calculated.

Complete concentrate feed mixtures were prepared at the Hinus Animal Feed Factory in Srebrenik.

Before the ducklings arrived at the facility, water and food were prepared in shallow drinkers and feeders for tempering. Feeding and feeding from small drinkers and feeders was done in the first week of fattening. After that, the ducklings were fed from hanging feeders, the height of which was regulated according to the age of the ducklings. Feeding the ducklings in this period was done using tin troughs with chains hung on the front of the box fence, which also had the ability to regulate the height according to the age of the ducklings. The ducklings had free access to food and water (ad libitum), and the building was lit for 24 hours. The raw material compositions of the mixtures used in duck fattening (starter and finisher) are shown in Tables 2 and 3.

Table 2. Raw material composition of starter fattening concentrate mixture

\begin{tabular}{|c|c|c|c|c|}
\hline \multirow{3}{*}{ Raw material $(\%)$} & \multicolumn{4}{|c|}{ Concentrated starter mixture (1st to 15th day) } \\
\hline & \multicolumn{4}{|c|}{ Experimental groups } \\
\hline & K0 & K1 & K2 & K3 \\
\hline Corn & 54,83 & 54,63 & 54,43 & 54,23 \\
\hline Soybean semolina & 18,00 & 18,00 & 18,00 & 18,00 \\
\hline Soybean meal & 16,00 & 16,00 & 16,00 & 16,00 \\
\hline Soy protein concentrate & 5,00 & 5,00 & 5,00 & 5,00 \\
\hline Alcoholic yeast & 2,50 & 2,50 & 2,50 & 2,50 \\
\hline Mono-Ca-phosphate & 1,30 & 1,30 & 1,30 & 1,30 \\
\hline Premix for fattening ducks I & 1,00 & 1,00 & 1,00 & 1,00 \\
\hline Livestock chalk & 0,90 & 0,90 & 0,90 & 0,90 \\
\hline
\end{tabular}




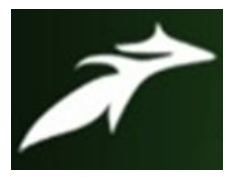

Amir Zenunović et al, International Journal of Advances in Agricultural Science and Technology, Vol.8 Issue.8, August-2021, pg. 102-109

ISSN: 2348-1358

Impact Factor: 6.057

NAAS Rating: 3.77

\begin{tabular}{|r|r|r|r|r|}
\hline Fodder salt & 0,35 & 0,35 & 0,35 & 0,35 \\
\hline Dl-Methiomin & 0,12 & 0,12 & 0,12 & 0,12 \\
\hline Organic selenium (Se) & - & 0,20 & 0,40 & 0,60 \\
\hline $\mathbf{\Sigma}$ & $\mathbf{1 0 0 , 0 0}$ & $\mathbf{1 0 0 , 0 0}$ & $\mathbf{1 0 0 , 0 0}$ & $\mathbf{1 0 0 , 0 0}$ \\
\hline
\end{tabular}

Tabela 3 Raw material composition of finisher fattening concentrate mixture

\begin{tabular}{|l|r|r|r|r|}
\hline \multirow{2}{*}{ Raw material (\%) } & \multicolumn{4}{|c|}{ Concentrated finisher mixture (15th to 49th day) } \\
\cline { 2 - 5 } & \multicolumn{3}{|c|}{ Experimental groups } \\
\cline { 2 - 5 } & \multicolumn{1}{|c|}{ K0 } & \multicolumn{2}{|c|}{ K1 } & \multicolumn{2}{c|}{ K3 } \\
\hline Corn & 72,02 & 71,82 & 71,62 & 71,42 \\
\hline Soybean semolina & 11,00 & 11,00 & 11,00 & 11,00 \\
\hline Soybean meal & 9,00 & 9,00 & 9,00 & 9,00 \\
\hline Soy protein concentrate & 2,50 & 2,50 & 2,50 & 2,50 \\
\hline Alcoholic yeast & 2,00 & 2,00 & 1,20 & 2,00 \\
\hline Mono-Ca-phosphate & 1,20 & 1,20 & 1,00 & 1,20 \\
\hline Premix for fattening ducks I & 1,00 & 1,00 & 0,90 & 1,00 \\
\hline Livestock chalk & 0,90 & 0,90 & 0,30 & 0,90 \\
\hline Fodder salt & 0,30 & 0,30 & 0,08 & 0,30 \\
\hline Dl-Methiomin & 0,08 & 0,08 & 0,40 & 0,08 \\
\hline Organic selenium (Se) & - & 0,20 & $\mathbf{1 0 0 , 0 0}$ & 0,60 \\
\hline $\boldsymbol{\Sigma}$ & $\mathbf{1 0 0 , 0 0}$ & $\mathbf{1 0 0 , 0 0}$ & & $\mathbf{1 0 0 , 0 0}$ \\
\hline
\end{tabular}

The calculated chemical composition of the mixtures used in duck fattening is shown in Tables 4 and 5 .

Table 4. Calculative chemical composition of concentrate mixture finisher for duck fattening

\begin{tabular}{|c|c|c|c|c|c|}
\hline \multirow{3}{*}{ Name } & \multirow{3}{*}{$\begin{array}{l}\text { Unit of } \\
\text { measure }\end{array}$} & \multicolumn{4}{|c|}{ Starter concentrate mixture (1st to 15th day) } \\
\hline & & \multicolumn{4}{|c|}{ Experimental groups } \\
\hline & & K0 & K1 & K2 & K3 \\
\hline Dry matter & $\%$ & 88,06 & 88,07 & 88,08 & 88,08 \\
\hline Crude proteins & $\%$ & 22,16 & 22,16 & 22,13 & 22,10 \\
\hline Crude fat & $\%$ & 5,73 & 5,72 & 5,72 & 5,71 \\
\hline Crude fiber & $\%$ & 3,34 & 3,34 & 3,33 & 3,33 \\
\hline $\mathrm{Ca}$ & $\%$ & 0,65 & 0,63 & 0,63 & 0,63 \\
\hline $\mathrm{Na}$ & $\%$ & 0,14 & 0,14 & 0,14 & 0,14 \\
\hline $\mathrm{Cl}$ & $\%$ & 0,20 & 0,20 & 0,20 & 0,20 \\
\hline $\mathrm{P}$ & $\%$ & 0,75 & 0,75 & 0,75 & 0,75 \\
\hline Lysine & $\%$ & 1,41 & 1,41 & 1,41 & 1,41 \\
\hline Methionine & $\%$ & 0,51 & 0,51 & 0,51 & 0,51 \\
\hline $\mathrm{A}$ & $\mathrm{IJ} / \mathrm{kg}$ & 10,00 & 10,00 & 10,00 & 10,00 \\
\hline D3 & $\mathrm{IJ} / \mathrm{kg}$ & 2,00 & 2,00 & 2,00 & 2,00 \\
\hline $\mathrm{E}$ & $\mathrm{mg} / \mathrm{kg}$ & 30,00 & 30,00 & 30,00 & 30,00 \\
\hline ME poultry & $\mathrm{MJ} / \mathrm{kg}$ & 13,19 & 13,16 & 13,13 & 13,10 \\
\hline
\end{tabular}




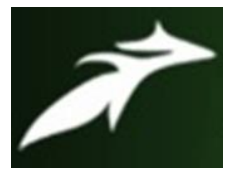

Amir Zenunović et al, International Journal of Advances in Agricultural Science and Technology, Vol.8 Issue.8, August-2021, pg. 102-109

ISSN: 2348-1358

Impact Factor: 6.057

NAAS Rating: 3.77

Table 5. Calculative chemical composition of concentrate mixture finisher for duck fattening

\begin{tabular}{|c|c|c|c|c|c|}
\hline \multirow{3}{*}{ Name } & \multirow{3}{*}{$\begin{array}{l}\text { Unit of } \\
\text { measure }\end{array}$} & \multicolumn{4}{|c|}{ Finisher concentrate mixture (15th to 49th day) } \\
\hline & & \multicolumn{4}{|c|}{ Experimental groups } \\
\hline & & K0 & K1 & $\mathbf{K 2}$ & K3 \\
\hline Dry matter & $\%$ & 87,31 & 87,32 & 87,32 & 87,33 \\
\hline Crude proteins & $\%$ & 16,09 & 16,08 & 16,08 & 16,05 \\
\hline Crude fat & $\%$ & 4,52 & 4,51 & 4,51 & 4,50 \\
\hline Crude fiber & $\%$ & 2,87 & 2,87 & 2,86 & 2,88 \\
\hline $\mathrm{Ca}$ & $\%$ & 0,58 & 0,58 & 0,58 & 0,58 \\
\hline $\mathrm{Na}$ & $\%$ & 0,12 & 0,12 & 0,12 & 0,12 \\
\hline $\mathrm{Cl}$ & $\%$ & 0,17 & 0,17 & 0,17 & 0,17 \\
\hline $\mathrm{P}$ & $\%$ & 0,67 & 0,67 & 0,67 & 0,67 \\
\hline Lysine & $\%$ & 0,96 & 0,96 & 0,96 & 0,96 \\
\hline Methionine & $\%$ & 0,41 & 0,41 & 0,41 & 0,41 \\
\hline $\mathrm{A}$ & $\mathrm{IJ} / \mathrm{kg}$ & 10,00 & 10,00 & 10,00 & 10,00 \\
\hline D3 & $\mathrm{IJ} / \mathrm{kg}$ & 2,00 & 2,00 & 2,00 & 2,00 \\
\hline$E$ & $\mathrm{mg} / \mathrm{kg}$ & 30,00 & 30,00 & 30,00 & 30,00 \\
\hline ME poultry & $\mathrm{MJ} / \mathrm{kg}$ & 13,38 & 13,35 & 13,32 & 13,28 \\
\hline
\end{tabular}

\section{Sensory analysis}

The selection of assessors for sensory analysis was performed according to ISO 8586-1 / 1993. Differences in the acceptability of duck meat were determined by the Rang test ISO 8587/2006.

For the sensory analysis, a ranking test with ten evaluators and two repetitions was used, which means that the total number of tests is 20 . A smaller sum of ranks means better acceptability.

\section{Results}

The results of sensory evaluation of breast and thigh meat with duck karabatak (thermally treated without the addition of oil, fat and salt) are shown in Tables 6 and 7.

Table 6. Sensory evaluation of duck breast meat

\begin{tabular}{|c|c|c|c|c|c|}
\hline \multicolumn{2}{|c|}{ Group label } & K0 & K1 & K2 & K3 \\
\hline \multicolumn{2}{|c|}{ Sum of ranks } & 62 & 59 & 43 & 56 \\
\hline \multirow{2}{*}{$\begin{array}{c}\text { The difference } \\
\text { according to }\end{array}$} & K0 & - & 3 & 19 & 6 \\
\cline { 3 - 6 } & K2 & - & - & 16 & 3 \\
\cline { 3 - 6 } & & - & - & 13 \\
\hline
\end{tabular}

Table 7. Sensory evaluation of drumstick meat with karabatak

\begin{tabular}{|c|c|c|c|c|c|}
\hline \multicolumn{2}{|l|}{ Group label } & K0 & K1 & $\mathrm{K} 2$ & K3 \\
\hline \multicolumn{2}{|l|}{ Sum of ranks } & 61 & 58 & 46 & 55 \\
\hline \multirow{3}{*}{$\begin{array}{l}\text { The difference } \\
\text { according to }\end{array}$} & K0 & - & 3 & 15 & 6 \\
\hline & K1 & - & - & 12 & 3 \\
\hline & K2 & - & - & - & 9 \\
\hline
\end{tabular}

From the results shown in Tables 6 and 7, it can be seen that the samples of K2 and K3 groups are better rated, ie more acceptable than the samples of $\mathrm{K} 1$ and $\mathrm{K} 0$ groups, given that they have a smaller sum of ranks. However, the difference between the compared sum of ranks is not statistically significant. In order for the difference between the sums of ranks to be significant at the level of $p<0.05$, it should be 21 , and for the level of $\mathrm{p}<0.01$, this difference should be 25.4. 


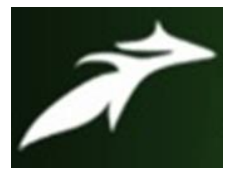

Amir Zenunović et al, International Journal of Advances in Agricultural Science and Technology, Vol.8 Issue.8, August-2021, pg. 102-109

ISSN: 2348-1358

Impact Factor: 6.057

NAAS Rating: 3.77

\section{Discussion}

Sensory evaluation did not reveal statistically significant differences between samples of duck meat from control and experimental groups. Although, the sum of ranks, which indicates better acceptability, was smaller in the experimental groups (the smallest in the $\mathrm{K} 2$ group). There is no data in the literature on the influence of selenium on the sensory properties of duck meat. The difference test used in our work determined the difference in acceptability between the control and experimental groups of ducks.

Overall acceptability means differences that are based on differences in all attributes of sensory properties (color, odor, taste, juiciness, softness, texture, etc.). It is understood that smell and taste are of the greatest importance in the assessment of overall acceptability. They are the result of a large number of compounds in meat, the most significant part of which is formed during heat treatment. Today, it is considered that the smell and taste are the consequences of the presence of over a thousand compounds in meat (carbohydrates, alcohols, aldehydes, ketones, esters, lactones, furals, etc.). Among the compounds that contribute to the smell and taste of meat are acyclic sulfur compounds, volatile sulfur compounds, heterocyclic nitrogen compounds and carbonyl compounds. Their quantity and ratio in the meat of different species is different and it contributes to the characteristic smell and taste for the meat of each animal species (Gaser and Gosch, 1990). As selenium is incorporated into cysteine in place of sulfur, there may be a change in the smell and taste of meat, as a result of a decrease in the amount of sulfur in proteins that has been replaced by selenium. This could only be proven by analyzing the presence of sulfur or its compounds in the meat after heat treatment.

Different genotypes of ducks (Muscovy, Peking duck and their hybrids Hinny and Mule), enhanced diet from 12 to 16 weeks and ad libitum diet to achieve different fat content in the pectoral muscles. The average value of intramuscular fat was between 2.55 and 6.40 grams per 100 grams of muscle. The breasts of overfed ducks had a higher fat content and a lower water content compared to ad libitum-fed ducks.

Also, the muscles of heavily fed ducks were paler, more yellow and had a greater loss of fluid during cooking. The juiciness was less, and the taste was more pronounced in more fed ducks. Male ducks had higher breast masses and lower fat content than other genotypes.

Fluid loss during cooking was greater in duck breast muscles that had a higher fat content, but this criterion was not associated with meat juiciness (Chartin et al., 2006a). Namely, the breasts of Muscovy ducks overfed had the lowest grade for juiciness, while the breasts of Peking duck fed ad libitum received the highest grade for juiciness. In that study, the measurement of liquid loss during cooking and juiciness was not done after the same cooking procedure, which may partly explain the differences between the criteria. By combining genotypes (Muscovy, Peking duck and their hybrids Hinny and Mule duck) and the level of nutrition (excessive and ad libitum) can affect so that the fat content in breast meat varies from 1.72 to $8.35 \%$. Sensory analysis shows that the increase in lipids causes an increase in the brightness of the color, loss of liquid during heat treatment, softening of the meat and acceptability of smells and tastes.

The correlation between the fat content and the mentioned persons is significant. Increasing the fat content with the age of ducks leads to a more intense smell and taste (Beaze et al., 2000, 2002).

In a study by Chartin et al. (2006a) juiciness was positively correlated with water content in breast meat and negatively correlated with breast mass. Other factors can affect the juiciness of meat.

The tenderness of the meat found by trained assessors was positively correlated with shear force. In a study by Chartin et al. (2006a), greater softness of breast meat was associated with higher fat content, but enhanced feeding that led to higher breast fat content did not significantly affect this sensory trait. Girard et al. (1993) also found that the breast meat of ad libitum-fed ducks was softer compared to over-fed ducks. In contrast, the breast meat of heavily fed Landaise geese, which had the highest fat content, was rated as the softest (Baeza et al., 1998). In a study by Chartin et al. (2006a), softness was very negatively correlated with breast mass, with the hardest meat being in Muscovy duck and the softest in Peking duck. Larzul et al. (2002) found that the meat of breast-fed malnourished Muscovy ducks had the highest collagen content ( $4.82 \mathrm{mg} / \mathrm{g}$ muscle) and the lowest collagen solubility (13\%) compared to Peking duck breast meat (4.30 mg / kg and 19\%). Chartrin et al. (2005) found that the cross-section of chest muscle fibers was higher in Muscovy compared to Peking duck (929 and $683 \mu \mathrm{m} 2$ for red oxidative fibers, and 2,028 and 1,608 $\mu \mathrm{m} 2$ for white glycolytic fibers, respectively). Muscovy duck meat was also the toughest, confirming the possible influence of muscle fiber diameter on these parameters. Baeza et al. $(1999,2000)$ found that the softness of the breast meat. 


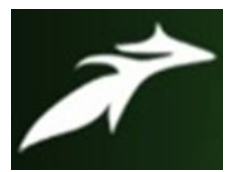

Amir Zenunović et al, International Journal of Advances in Agricultural Science and Technology, Vol.8 Issue.8, August-2021, pg. 102-109

ISSN: 2348-1358

Impact Factor: 6.057

NAAS Rating: $\mathbf{3 . 7 7}$

\section{Conclusion}

Based on the obtained results of sensory analysis of tested samples of breast meat, ie meat of drumsticks with karabatak in ducks fed concentrate mixtures with different selenium content in the same Rang-test, no statistically significant differences were found in the assessment of overall acceptability of meat of examined groups of ducks.

\section{References}

[1]. Ali, M.S., Kang, G.H., Yang, H.S., Jeong, J.Y., Hwang, Y.H., Park, G.B., Joo, S.T. (2007a): A comparison of meat characteristics between duck and chicken breast. Asian-Austral. J. of Anim. Sci. 20(6): 1002-1006.

[2]. Beaza, E. and Leclercq B. (1998) Use of industrial amino acids to allow low protein concentrations in finishing diets for rowing Muskowy ducks. British Poultry Science 39:90-96.

[3]. Baeza E., Marche G., Wacrenier N., 1999, Effect of sex on muscular development of Muscovy ducks. Reproduction, Nutrition, Development 39: 675-682.

[4]. Rabot, C. (1998): Vitesse de croissanceet caracte' risriques lipidiques et senzorielles des muscles de poulet. PhD Thesis. Inst. Natl.Agron. Paris-Grignon, France.

[5]. Baéza, E., Salichon, M. R., Marché, G., Wacrenier, N., Dominguez, B., Culioli, J. (2000): Effects of age and sex on the structural, chemical and technological characteristics of mule duck meat. Brit. Poult. Sci. 41: 300-307.

[6]. Baeza E., Dessay C., Wacrenier N., Marche G., Listrat A., 2002, Effect of selection for improved body weight and composition on muscle and meat characteristics in Muscovy duck. British Poultry Science 43: 560-568.

[7]. Baeza E., 2006. Major trends in research into domestic ducks and recent results concerning meat quality, In: European Poultry Conference (p. 8 p.). World's Poultry Science Journal, 62. Presented at 12. European Poultry Conference, Verone, ITA (2006-09-10 - 2006-09-14). ITA: World's poultry science association- Italian Branch. http://prodinra.inra.fr/record/17476.

[8]. Chartrin, P., Mourot, J., Bernadet, M.D., Guy, G., Duclos, M.J., Baéza, E. (2003): Effect of genotype and force feeding on the intramuscular fat deposition in duck. Pages 224-230 in Proc. $16^{\text {th }}$ Eur. Symp. Qual. Poult. Meat, Saint-Brieuc, France. ISPAIA, Ploufragan, France.

[9]. Chartrin P., Meteau K., Juin H., Bernadet M.D., Guy G., Larzul C., Remignon H., Mourot J., Duclos M.J., Baeza E., 2006a, Effects of intramuscular levels on sensory characteristics of duck breast meat. Poultry Science, in press.

[10].Čepin, S., Čepon, M. (2001): Uticaj genetike i sredine na kvalitet junećeg trupa mesa, Tehnologija mesa, 42, 5 - 6, 283 - 284.

[11].Dupler, D. (2001): Essential Fatty Acids, Gale Encyclopedia of Alternative Medicine, Gale Group.

[12].Domaćinović M., 2006, Hranidba domaćih životinja. Poljoprivredni fakultet, Osijek.

[13].Džinić Natalija, Tomović,V., Petrović Ljiljana, Perić Lidija (2006): Uticaj dodataka selena različitog porekla u hranu za piliće na kvalitet Mm. pectoralis. Tehnologija mesa, 47, 5 - 6, $199-203$.

[14].Froning, G.W. (1995):Colour of poultry meat. Poult. Avian Biol.Rev.6:83 - 93.

[15].Gaser U., Grosch W. (1990): Primary odourants of chicken broth, Z. Lebenm. Unters. Forsch, 190, 3 -8 .

[16].Gandemer G., 1997, Lipides du muscle et qualite de la viande. Phospolipides et flaveur. OCL-Ol. Corps Gras Lipides 41, 19-25.

[17].Girard J.P., Culioli J., Denoyer C., Berdague J.L., Touraille C., 1993, Discrimination de deux populations chez deux especes de volaille sur la base de leur composition en lipides. Arch. Geflugelkd. 57, 9-15.

[18].Hargins, P. S. and Elswyk, M.E. (1993): Manipulating the fatty acid composition of poultry meat and eggs for the health comscious consumer, World's science Journal, 49, $252-264$. 


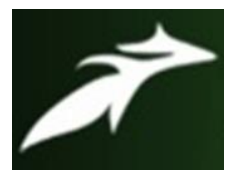

Amir Zenunović et al, International Journal of Advances in Agricultural Science and Technology, Vol.8 Issue.8, August-2021, pg. 102-109

ISSN: 2348-1358

Impact Factor: 6.057

NAAS Rating: 3.77

[19].Janssens, G. (1998): Vitamin E improves chickens meat quality, Meat processing International Edition. September/October, 42: $44-46$.

[20].Larzur, C., Imbert, B., Bernadet, M. D., Guy, G., Remignon, H. (2002): Qualite du magret dans un croisement factoriel Barbarie X INRA 44. 5emes Journees de la Recherce sur les Palmipedes a Foie Gras, Pau, France 9-10/10/02: 29-32.

[21].Lin, F. C., Gray, J. I., Ashgar, A., Buckley, D. J., Booren, A. M. and Flegal, C. J. (1989): Effects of dietary oils and $\alpha$-tocopherol supplementation on lipid composition and stability of broiler meat, J. Food Sci., 54, $1457-1460$.

[22].Mahan, D. C. and Y. Y. Kim. (1999): The role of vitamins and minerals in the production of high quality pork. Review. Asian-Australian J. Anim. Sci. 12:287 - 294.

[23]. Marković Radmila (2007): Uticaj selena organskog i neorganskog porekla i različite količine vitamina E na proizvodne rezultate i kvalitet mesa brojlera. Doktorska disertacija, Beograd.

[24].Meunier A., Gandemer G., 1994, La flaveur des viandes cuites: Relations avec L oxydation des phospholipides. Viandes et Produits Carnes 15, 179-182.

[25].Newman, R. E., Bryden, L. W., Fleck, E., Ashes, J. R., William, A., Buttemer, W. A., Storlien, L. H. and Dowing, J. A. (2002): Dietary n-3 and n-6 fatty acids alter avian metabolism: metabolism and abdominal fat deposition, British Journal of Nutrition, 88, 11-18.

[26]. Okuynama, H. and Ikemoto, A. (1999): Need to modified the fatty acid of meat for human health, Proceedings of $45^{\text {th }}$ ICoMST, Yokohama, Japan, $638-639$.

[27].Rede, R. R., Ljiljana S. Petrović (1997): Tehnologija mesa i nauka o mesu, Tehnološki fakultet, Univerzitet u Novom Sadu, Novi Sad, ss. $1-512$.

[28].Sheehy, P. J., P. A. Morrissey, D. J. Buckley and J. Wen. (1997): Effects of vitamins in the feed on meat quality in farm animals: Vitamin E. In: Recent advances in animal nutrition. (P.C. Garnsworthy and J.Wiseman, eds.) Notthingham University Press, Nottingham, pp. 3-27. 